JEL Classification: L 98

\title{
ЗАКОНОДАВЧЕ ЗАБЕЗПЕЧЕННЯ РОЗВИТКУ ТРАНСПОРТНОЇ ІНФРАСТРУКТУРИ УКРАЇНИ
}

\section{Дмитрієва О.І., к.е.н, доцент}

\section{Харківський національний автомобільно-дорожній університет}

Постановка проблеми. Основою національного господарства країни $\epsilon$ транспортна система, ефективність функціонування якої визначається рівнем розвитку транспортної інфраструктури. Наразі Україна посідає 87-е місце у світі за рівнем розвитку транспортної інфраструктури [1]. При цьому за значенням субіндексу «Інфраструктура» індексу Глобальної конкурентоспроможності найгіршим інфраструктурним показником України $\epsilon$ якість доріг - 130-е місце зі 137-и можливих. Незадовільними залишаються якість авіаційної та портової інфраструктури України (92-е і 93-е місця, відповідно). Єдиною відносно розвиненою складовою транспортної інфраструктури в Україні є залізнична інфраструктура - 37-е місце [2]. Якість транспортної інфраструктури нині здійснює переважно деструктивний вплив на конкурентоспроможність вітчизняної економіки та міжнародний імідж України як транспортного хабу між Європою та Азією. Транспортна інфраструктура країни зазвичай має змішану форму власності, адже окремі іiі елементи знаходяться у власності держави, а деякі об'єкти - у власності приватного сектору. Зазначеним створюються сприятливі умови для державно-приватного партнерства та забезпечується вплив держави на розвиток транспортної інфраструктури через застосування комплексу правових, адміністративних i економічних методів. При цьому в системі методів державного регулювання розвитку транспортної інфраструктури чільне місце належить правовому методу, що полягає в регламентації розвитку транспортної інфраструктури нормами актів законодавчої та виконавчої влади. У таких умовах актуалізується необхідність дослідження законодавчого підгрунтя розвитку транспортної інфраструктури України.

Аналіз останніх досліджень i публікацій. Проблемам розвитку транспортної інфраструктури України присвячені праці таких вітчизняних дослідників як О. Амосов, Н. Безбах, В. Бондар, Н. Бондар, Н. Бортник, В. Брагінський, О. Васильєв, А. Возненко, Л. Волинець, В. Гамалій, Р. Григоренко, Ю. Грисюк, Р. Гудима, В. Гурнак, О. Дейнека, А. Дем’янченко, Х. Дорофєєва, С. Дульфан, С. Ссімов, В. Жаворонков, Г. Жовтяк, Т. Затонацька, О. Ігнатенко, В. Карпов, О. Кириленко, С. Козловська, В. Командровська, А. Кравченко, О. Криворучко, Н. Кудрицька, В. Кутирєв, Н. Кучеренко, I. Лебідь, Т. Логвинюк, Т. Логутова, О. Лук'янова, С. Луцкін, І. Любезна, О. Ляшенко, М. Макаренко, Н. Малиш, Т. Машошина, Т. Момот, О. Никифорук, П. Нікітін, О. Носовська, О. Озерова, А. Пасічник, Ю. Пащенко, М. Підгорний, О. Поліщук, М. Полторацький, О. Полякова, Г. Родащук, О. Рудченко, I. Садловська, Ю. Світлична, I. Середюк, Н. Серьогіна, А. Слободян, О. Солодовнік, Л. Сотниченко, О. Суворкіна, П. Толок, 
Ю. Третиниченко, О. Тройнікова, С. Тхор, Р. Устинов, Г. Фоменко, Л. Харсун, I. Хоменко, І. Хорошилова, Н. Цебенко, О. Цибенко, Н. Цимбал, А. Шевченко, В. Шемаєв, О. Шиба, Л. Шкварчук, А. Шутенко та інших науковців.

Питанню нормативно-правового забезпечення розвитку транспортної інфраструктури України приділено увагу в дослідженні О. Ляшенко, якою було виділено такі акти органів законодавчої та виконавчої влади, що регламентують розвиток окремих елементів транспортної інфраструктури: повітряного транспорту - Конвенцію для уніфікації деяких правил, що стосуються міжнародних повітряних перевезень, Конвенцію про міжнародну цивільну авіацію, Угоду про цивільну авіацію та про використання повітряного простору, Повітряний кодекс України, Закон України «Про Державну програму авіаційної безпеки цивільної авіації», Указ Президента України «Про заходи щодо забезпечення розвитку цивільної авіації України», Постанову Кабінету Міністрів України «Про затвердження переліку небезпечних предметів i речовин, заборонених до перевезення повітряним транспортом», Постанову Кабінету Міністрів України «Про затвердження Порядку і правил проведення обов'язкового авіаційного страхування цивільної авіації», Постанову Кабінету Міністрів України «Про серйозні недоліки в роботі та невідкладні заходи щодо поліпшення діяльності цивільної авіації», Постанову Кабінету Міністрів України «Про порядок повітряного сполучення через державний кордон України», Положення про використання повітряного простору України, Правила реєстрації цивільних аеродромів України, Правила реєстрації цивільних повітряних суден в Україні; залізничного транспорту - Закон України «Про залізничний транспорт», Закон України «Про особливості утворення публічного акціонерного товариства залізничного транспорту загального користування», Порядок обслуговування громадян залізничним транспортом, Правила перевезення пасажирів, багажу, вантажобагажу та пошти залізничним транспортом України, Положення про Державну адміністрацію залізничного транспорту України, Постанову Кабінету Міністрів України «Про затвердження Статуту залізниць України», Постанову Кабінету Міністрів України «Про затвердження переліку категорій та посад працівників залізничного транспорту, які працевлаштовуються за контрактною формою трудового договору», Наказ Міністерства інфраструктури України «Про затвердження Тарифів на перевезення пасажирів, багажу і вантажобагажу залізничним транспортом у внутрішньому сполученні», Положення про відомчу воєнізовану охорону на залізничному транспорті, Положення про систему управління безпекою руху поїздів у Державній адміністрації залізничного транспорту України, Правила пожежної безпеки на залізничному транспорті, Порядок оформлення матеріалів про адміністративні правопорушення на залізничному транспорті, Інструкцію про порядок взаємодії між органами внутрішніх справ, залізницями України і підприємствами залізничного транспорту під час виявлення крадіжок вантажу та реагування на заяви і повідомлення про такі правопорушення, Порядок взаємодії підрозділів відомчої воєнізованої охорони на залізничному транспорті та лінійних 
підрозділів транспортної міліції, Інструкцію про взаємодію посадових осіб митних органів, що здійснюють митні процедури 3 товарами (вантажами), переміщуваними залізничними вантажними поїздами, і працівників залізниць України, Інструкцію про взаємодію посадових осіб митних органів, що здійснюють митні процедури з багажем і вантажобагажем, переміщуваними в багажних вагонах, і працівників залізниць України; морського та річкового транспорту - Міжнародну конвенцію 3 охорони людського життя на морі, Кодекс торговельного мореплавства України, Водний кодекс України, Закон України «Про морські порти України», Положення про Регістр судноплавства України, Положення про робочий час та час відпочинку плаваючого складу морського і річкового транспорту України, Положення про морських лоцманів, Положення про державних річкових лоцманів, Положення про порядок підготовки та подання інформації про вантаж для його безпечного морського перевезення, Правила безпечної експлуатації баз для стоянки маломірних (малих) суден; автомобільного транспорту - Закон України «Про автомобільний транспорт», Порядок проведення конкурсу 3 перевезення пасажирів на автобусному маршруті загального користування, Порядок здійснення державного контролю на автомобільному транспорті, Правила надання послуг пасажирського автомобільного транспорту, Порядок регулювання діяльності автостанцій, Порядок визначення класу комфортності автобусів, сфери їхнього використання за видами сполучень та режимами руху, Положення про ліцензійну картку, що додається до ліцензії на надання послуг 3 перевезення пасажирів і вантажів автомобільним транспортом, Наказ Міністерства транспорту та зв'язку України «Про затвердження Ліцензійних умов провадження господарської діяльності з надання послуг 3 перевезення пасажирів і вантажів автомобільним транспортом відповідно до видів робіт, визначених Законом України «Про автомобільний транспорт»» [3]. С. Дульфан також здійснив аналіз нормативно-правової бази розвитку транспортної інфраструктури України, виділивши у якості законодавчого підгрунтя Закон України «Про транспорт», Закон України «Про автомобільний транспорт», Закон України «Про міський електричний транспорт» та Транспортну стратегію України до 2020 року [4].

Невирішені складові загальної проблеми. Традиційно для України є характерною суттєва динамічність нормативно-правової бази: так, зокрема, на даний момент відбулася зміна Правил реєстрації цивільних повітряних суден в Україні (Наказ Державної авіаційної служби України від 5 лютого 2019 року № 153) [5]; втратили чинність Положення про ліцензійну картку, що додається до ліцензії на надання послуг 3 перевезення пасажирів i вантажів автомобільним транспортом, i Наказ Міністерства транспорту та зв'язку України «Про затвердження Ліцензійних умов провадження господарської діяльності з надання послуг з перевезення пасажирів і вантажів автомобільним транспортом відповідно до видів робіт, визначених Законом України «Про автомобільний транспорт»») [6]; Транспортна стратегія України до 2020 року достроково була замінена на Національну транспортну стратегію України на 
період до 2030 року (Розпорядження Кабінету Міністрів України від 30 травня 2018 року № 430-p) [7]. Також вважаємо за доцільне включити до законодавчого підгрунтя розвитку транспортної інфраструктури й нормативноправові акти, нормами яких регламентується: функціонування дорожнього господарства як важливого фактору забезпечення розвитку автомобільного транспорту; функціонування трубопровідного транспорту.

Формулювання цілей статті. Метою статті $є$ ідентифікація чинного законодавчого підгрунтя розвитку транспортної інфраструктури України.

Виклад основного матеріалу дослідження. Скориставшись пошуковою системою «Законодавство України», виявимо чинну нормативно-правову базу розвитку транспортної інфраструктури України - універсальну та за видами транспорту. Так, до «універсальної» частини законодавчої бази розвитку транспортної інфраструктури віднесемо Закон України «Про транспорт» i Національну транспортну стратегію України на період до 2030 року.

Автомобільний транспорт. Діяльність суб'єктів автомобільного транспорту наразі регламентується нормами: Закону України «Про автомобільний транспорт»; Правил перевезень вантажів автомобільним транспортом в Україні; Правил надання послуг пасажирського автомобільного транспорту; Порядку проведення конкурсу 3 перевезення пасажирів на автобусному маршруті загального користування; Порядку визначення класу комфортності автобусів, сфери їхнього використання за видами сполучень та режимами руху; Порядку розроблення та затвердження паспорта автобусного маршруту; Порядку формування, затвердження та ведення реєстру міжнародних, міжміських та приміських автобусних маршрутів загального користування; Закону України «Про приєднання України до Європейської угоди щодо роботи екіпажів транспортних засобів, які виконують міжнародні автомобільні перевезення (СУТР)»; Постанови Кабінету Міністрів України «Про виконання Свропейської угоди щодо роботи екіпажів транспортних засобів, які виконують міжнародні автомобільні перевезення (ЄУТР)»; Закону України «Про приєднання України до Угоди про міжнародні нерегулярні перевезення пасажирів автобусами (Угода INTERBUS)»; Постанови Кабінету Міністрів України «Про затвердження критеріїв, за якими оцінюється ступінь ризику від провадження господарської діяльності 3 перевезення пасажирів, небезпечних вантажів та небезпечних відходів автомобільним транспортом, міжнародних перевезень пасажирів та вантажів автомобільним транспортом та визначається періодичність здійснення планових заходів державного нагляду (контролю) Державною службою з безпеки на транспорті»; Порядку організації регулярних, нерегулярних і маятникових перевезень пасажирів автомобільним транспортом у міжнародному сполученні; Наказу Міністерства внутрішніх справ України «Про убезпечення перевезення небезпечних вантажів автомобільним транспортом»; Умов охорони небезпечних і цінних вантажів під час їх перевезення автомобільним транспортом та переліку таких вантажів; Указу Президента України «Про заходи щодо посилення безпеки пасажирських перевезень автомобільним транспортом»; Правил охорони праці на 
автомобільному транспорті; Правил пожежної безпеки для підприємств i організацій автомобільного транспорту України; Порядку перевірки технічного стану транспортних засобів автомобільними перевізниками; Постанови Кабінету Міністрів України «Деякі питання допуску автобусів до експлуатації»; Порядку державної реєстрації (перереєстрації), зняття з обліку автомобілів, автобусів, а також самохідних машин, сконструйованих на шасі автомобілів, мотоциклів усіх типів, марок і моделей, причепів, напівпричепів, мотоколясок, інших прирівняних до них транспортних засобів та мопедів; Наказу Міністерства транспорту України «Про впорядкування системи оформлення, видачі, використання та обліку дозволів на міжнародні перевезення пасажирів $і$ вантажів автомобільним транспортом»; Положення про зону сервісного обслуговування осіб і транспортних засобів перед пунктами пропуску через державний кордон для міжнародного та міждержавного автомобільного сполучення; Постанови Кабінету Міністрів України «Про затвердження Переліку документів, необхідних для здійснення перевезення вантажу автомобільним транспортом у внутрішньому сполученні»; Наказу Міністерства транспорту та зв'язку України «Про затвердження Методики розрахунку тарифів на послуги пасажирського автомобільного транспорту»; Наказу Міністерства транспорту України «Про затвердження Тарифів на проїзд пасажирів i перевезення багажу в автобусах міжміських міжобласних маршрутів»; Порядку регулювання діяльності автостанцій; Порядку здійснення державного контролю на автомобільному транспорті [8].

Дорожсе господарство. Функціонування дорожнього господарства України сьогодні регламентують положення таких нормативно-правових актів: Закону України «Про автомобільні дороги»; Постанови Кабінету Міністрів України «Про затвердження переліку автомобільних доріг загального користування державного значення»; Розпорядження Кабінету Міністрів України «Про схвалення Концепції Державної цільової економічної програми розвитку автомобільних доріг загального користування державного значення на 2018-2022 роки»; Положення про Державне агентство автомобільних доріг України; Постанови Кабінету Міністрів України «Про заходи щодо збереження автомобільних доріг загального користування»; Указу Президента України «Про заходи щодо підвищення ефективності управління дорожнім господарством України»; Указу Президента України «Про деякі заходи щодо створення умов для розвитку та підвищення якості автомобільних доріг»; Технічних правил ремонту і утримання вулиць та доріг населених пунктів; Постанови Кабінету Міністрів України «Про затвердження вимог щодо проведення контролю якості робіт 3 нового будівництва, реконструкції та капітального ремонту автомобільних доріг загального користування»; Розпорядження Кабінету Міністрів України «Питання розроблення та затвердження проектної документації для будівництва, реконструкції та капітального ремонту автомобільних доріг»; Указу Президента України «Про концесію на будівництво та реконструкцію автомобільних доріг»; Порядку визначення об'єктів концесії на будівництво та експлуатацію автомобільних 
доріг загального користування; Порядку проведення концесійного конкурсу на будівництво та експлуатацію автомобільних доріг комунальної власності; Положення про конкурсну комісію 3 проведення концесійних конкурсів на будівництво та експлуатацію автомобільних доріг; Розпорядження Кабінету Міністрів України «Деякі питання реформування системи державного управління автомобільними дорогами загального користування»; Наказу Міністерства інфраструктури України «Про затвердження Методики визначення обсягу фінансування будівництва, реконструкції, ремонту та утримання автомобільних доріг та нормативів витрат, пов'язаних з утриманням автомобільних доріг»; Закону України «Про джерела фінансування дорожнього господарства України»; Порядку спрямування коштів спеціального фонду державного бюджету на будівництво, реконструкцію та ремонт доріг комунальної власності; Конвенції Міжнародної організації праці про тривалість робочого часу та періоди відпочинку на дорожньому транспорті; Норм безплатної видачі спеціального одягу, спеціального взуття та інших засобів індивідуального захисту працівникам дорожнього господарства; Правил охорони праці під час будівництва, ремонту та утримання автомобільних доріг; Положення про функціональну підсистему запобігання і реагування на загрозу або виникнення надзвичайних ситуацій у дорожньому господарстві [8].

Залізничний транспорт. Перевезення пасажирів і вантажів залізничним транспортом, утримання та розвиток залізниць в Україні здійснюється у відповідності до норм актів органів законодавчої та виконавчої влади, таких як: Закон України «Про залізничний транспорт»; Стратегія розвитку залізничного транспорту на період до 2020 року; Концепція Державної програми реформування залізничного транспорту; Постанова Кабінету Міністрів України «Про заходи державної підтримки залізничного транспорту»; Правила перевезення пасажирів, багажу, вантажобагажу та пошти залізничним транспортом України; Ліцензійні умови провадження господарської діяльності 3 перевезення пасажирів, небезпечних вантажів та небезпечних відходів залізничним транспортом; Технічний регламент надання послуг з перевезення пасажирів та вантажів залізничним транспортом; Положення про сертифікаційну діяльність на залізничному транспорті України; Постанова Кабінету Міністрів України «Про затвердження Статуту залізниць України»; Закон України «Про особливості утворення публічного акціонерного товариства залізничного транспорту загального користування»; Положення про Державну адміністрацію залізничного транспорту України; Постанова Кабінету Міністрів України «Про затвердження критеріїв, за якими оцінюється ступінь ризику від провадження господарської діяльності у сфері перевезення пасажирів, небезпечних вантажів та небезпечних відходів залізничним транспортом та визначається періодичність здійснення планових заходів державного нагляду (контролю) Державною службою з безпеки на транспорті»; Порядок обслуговування громадян залізничним транспортом; Правила поведінки громадян на залізничному транспорті; Правила безпеки громадян на залізничному транспорті України; Порядок оформлення розрахункових i 
звітних документів при здійсненні продажу проїзних і перевізних документів на залізничному транспорті; Порядок застосування електронного документообігу, пов'язаного 3 перевезенням вантажів залізничним транспортом; Порядок застосування електронного перевізного документа під час перевезення вантажів залізничним транспортом; Порядок організації діяльності залізничного транспорту під час здійснення військових залізничних перевезень; Постанова Кабінету Міністрів України «Про затвердження модулів оцінки відповідності у сфері залізничного транспорту»; Наказ Міністерства інфраструктури України «Про затвердження Методики розрахунку тарифів на перевезення пасажирів залізничним транспортом»; Наказ Міністерства інфраструктури України «Про затвердження Методики розрахунку тарифів на перевезення вантажів залізничним транспортом»; Наказ Міністерства інфраструктури України «Про затвердження Тарифів на перевезення пасажирів, багажу i вантажобагажу залізничним транспортом у внутрішньому сполученні»; Збірник тарифів на перевезення вантажів залізничним транспортом у межах України та пов'язані 3 ними послуги і коефіцієнти, що до нього застосовуються; Наказ Міністерства транспорту та зв’язку України «Про встановлення Тарифів на перевезення пасажирів, багажу та вантажобагажу залізничним транспортом у міжнародному сполученні»; Наказ Міністерства інфраструктури України «Про затвердження тарифів на перевезення залізничним транспортом вантажів транзитом через територію України»; Постанова Кабінету Міністрів України «Про забезпечення прозорості державної тарифної політики щодо перевезення вантажів залізничним транспортом у межах України»; Порядок перегляду тарифів на перевезення пасажирів залізничним транспортом; Порядок перегляду тарифів на перевезення вантажів залізничним транспортом; Порядок розрахунку обсягів компенсаційних виплат за пільгові перевезення залізничним транспортом окремих категорій громадян; Постанова Кабінету Міністрів України «Про встановлення пільгового тарифу на перевезення дітей залізничним транспортом»; Постанова Кабінету Міністрів України «Про знаки розрізнення i формений одяг працівників залізничного транспорту»; Положення про порядок проведення атестації керівних, інженерно-технічних працівників та інших спеціалістів підприємств і організацій залізничного транспорту України; Програма забезпечення житлом працівників залізничного транспорту; Норми безоплатної видачі спеціального одягу, спеціального взуття та інших засобів індивідуального захисту працівникам залізничного транспорту; Порядок проведення медичних оглядів працівників певних категорій залізничного транспорту, метрополітенів та підприємств міжгалузевого промислового залізничного транспорту України; Правила безпеки для працівників залізничного транспорту на електрифікованих лініях; Правила з охорони праці під час ремонту та експлуатації будівель і споруд залізничного транспорту; Правила охорони праці під час виконання навантажувально-розвантажувальних робіт на залізничному транспорті; Положення про систему управління безпекою руху поїздів у Державній адміністрації залізничного транспорту України; Технічний регламент безпеки рухомого складу залізничного 
транспорту; Технічний регламент безпеки інфраструктури залізничного транспорту; Правила пожежної безпеки на залізничному транспорті; Інструкція зі службового розслідування, обліку пожеж та наслідків від них на залізничному транспорті; Наказ Міністерства транспорту України «Про охорону і супроводження вантажів, що перевозяться залізничним транспортом України»; Правила безпеки та порядок ліквідації наслідків аварійних ситуацій 3 небезпечними вантажами при перевезенні їх залізничним транспортом; Наказ Міністерства інфраструктури України «Про затвердження Порядку технічного розслідування катастроф, аварій, дорожньо-транспортних пригод, подій на залізничному транспорті»; Положення про класифікацію транспортних подій на залізничному транспорті; Положення про функціональну підсистему запобігання і реагування на загрозу або виникнення надзвичайних ситуацій на залізничному транспорті; Положення про відомчу воєнізовану охорону на залізничному транспорті; Інструкція про порядок взаємодії між органами внутрішніх справ, залізницями України і підприємствами залізничного транспорту під час виявлення крадіжок вантажу та реагування на заяви i повідомлення про такі правопорушення; Порядок оформлення матеріалів про адміністративні правопорушення на залізничному транспорті; Порядок взаємодії підрозділів відомчої воєнізованої охорони на залізничному транспорті та лінійних підрозділів транспортної міліції; Інструкція про взаємодію посадових осіб митних органів, що здійснюють митні процедури 3 товарами (вантажами), переміщуваними залізничними вантажними поїздами, i працівників залізниць України; Інструкція про взаємодію посадових осіб митних органів, що здійснюють митні процедури з багажем і вантажобагажем, переміщуваними в багажних вагонах, і працівників залізниць України [8].

Повітряний транспорт. Діяльність суб'єктів повітряного транспорту України регламентується нормами таких нормативно-правових актів: Конвенції про міжнародну цивільну авіацію; Конвенції для уніфікації деяких правил, що стосуються міжнародних повітряних перевезень; Конвенції про боротьбу 3 незаконними актами по відношенню до міжнародної цивільної авіації; Декларації глобальних принципів лібералізації міжнародного повітряного транспорту; Угоди про цивільну авіацію та про використання повітряного простору; Повітряного кодексу України; Положення про використання повітряного простору України; Ліцензійних умов провадження господарської діяльності з перевезення пасажирів, небезпечних вантажів та небезпечних відходів повітряним транспортом; Закону України «Про Державну програму авіаційної безпеки цивільної авіації»; Указу Президента України «Про заходи щодо забезпечення розвитку цивільної авіації України»; Указу Президента України «Про заходи щодо забезпечення безпеки повітряного транспорту України»; Порядку обліку та звіту регулярності польотів повітряних суден цивільної авіації України; Положення про передпольотне інформаційне обслуговування на аеродромах цивільної авіації України; Положення про медичний пункт аеровокзалу цивільної авіації України; Інструкції з організації перевезень вантажів повітряним транспортом; Постанови Кабінету Міністрів 
України «Про затвердження переліку небезпечних предметів і речовин, заборонених до перевезення повітряним транспортом»; Постанови Кабінету Міністрів України «Про затвердження Порядку i правил проведення обов'язкового авіаційного страхування цивільної авіації»; Порядку взаємодії Державної авіаційної служби 3 правоохоронними органами 3 питань забезпечення безпеки цивільної авіації; Постанови Кабінету Міністрів України «Про серйозні недоліки в роботі та невідкладні заходи щодо поліпшення діяльності цивільної авіації»; Правил аварійно-рятувального та протипожежного забезпечення польотів у цивільній авіації України; Положення про службу аварійно-рятувального та протипожежного забезпечення підприємства цивільної авіації України; Постанови Кабінету Міністрів України «Про утворення Національного бюро 3 розслідування авіаційних подій та інцидентів 3 цивільними повітряними суднами»; Постанови Кабінету Міністрів України «Про утворення Міжвідомчої комісії з авіаційної безпеки цивільної авіації»; Правил проведення службового розслідування актів незаконного втручання в діяльність цивільної авіації; Інструкції з організації та здійснення об'єктивного контролю при обслуговуванні повітряного руху та виробничій діяльності цивільної авіації України; Правил організації і проведення наземних та льотних перевірок наземних засобів радіотехнічного забезпечення польотів, авіаційного електрозв'язку та світлосигнального обладнання аеродромів цивільної авіації України; Правил реєстрації цивільних повітряних суден в Україні; Правил сертифікації наземних засобів радіотехнічного забезпечення в цивільній авіації України; Сертифікаційних вимог до наземних засобів радіотехнічного забезпечення в цивільній авіації України; Правил технічної експлуатації наземних засобів радіотехнічного забезпечення в цивільній авіації України; Правил реєстрації цивільних аеродромів України; Постанови Кабінету Міністрів України «Про порядок повітряного сполучення через державний кордон України»; Порядку виконання митних формальностей на повітряному транспорті; Правил визначення робочого часу та часу відпочинку екіпажів повітряних суден цивільної авіації України; Порядку накладення і стягнення штрафів за порушення вимог законодавства на повітряному транспорті [8].

Морський і річковий транспорт. Провадження діяльності з перевезення пасажирів і вантажів із використанням водним шляхів здійснюється в Україні у відповідності до норм: Міжнародної конвенції з охорони людського життя на морі; Кодексу торговельного мореплавства України; Водного кодексу України; Стратегії імплементації положень директив та регламентів Європейського Союзу у сфері міжнародного морського та внутрішнього водного транспорту («дорожньої карти»); Розпорядження Кабінету Міністрів України «Деякі питання функціонування морського та річкового транспорту»; Ліцензійних умов провадження господарської діяльності 3 перевезення пасажирів, небезпечних вантажів та небезпечних відходів річковим, морським транспортом; Закону України «Про морські порти України»; Положення про Регістр судноплавства України; Постанови Кабінету Міністрів України «Про затвердження критеріїв, за якими оцінюється ступінь ризику від провадження 
господарської діяльності у сферах перевезення пасажирів, небезпечних вантажів, небезпечних відходів морським і річковим транспортом та безпеки на морському та річковому транспорті (крім сфери безпеки мореплавства суден флоту рибної промисловості) та визначається періодичність проведення планових заходів державного нагляду (контролю) Державною службою морського та річкового транспорту»; Постанови Кабінету Міністрів України «Про утворення Державної служби морського та річкового транспорту України»; Постанови Кабінету Міністрів України «Про заходи щодо підвищення рівня безпеки на морському та річковому транспорті»; Постанови Кабінету Міністрів України «Про вдосконалення технічного, класифікаційного і судноплавного нагляду на морському і річковому транспорті»; Положення про систему управління безпекою судноплавства на морському i річковому транспорті; Правил оформлення вантажних перевізних документів на перевезення морським транспортом; Порядку визначення обсягів продукції (робіт, послуг) у порівнянних цінах на підприємствах морського та річкового транспорту; Положення про робочий час та час відпочинку плаваючого складу морського і річкового транспорту України; Порядку і норм видачі, терміни i правила носіння предметів форменого одягу та знаків розрізнення працівниками морського i річкового транспорту; Положення про морських лоцманів; Положення про державних річкових лоцманів; Положення про порядок підготовки та подання інформації про вантаж для його безпечного морського перевезення; Правил безпечної експлуатації баз для стоянки маломірних (малих) суден; Положення про функціональну підсистему запобігання і реагування на загрозу або виникнення надзвичайних ситуацій на морському i річковому транспорті в акваторії морських портів, організації пошуково-рятувальних робіт в акваторії Чорного та Азовського морів; Положення про відомчу пожежну охорону об'єктів морського і річкового транспорту України; Порядку оформлення матеріалів про адміністративні правопорушення на морському та річковому транспорті; Порядку виконання митних формальностей на морському та річковому транспорті [8].

Міський електричний транспорт. Експлуатація міського електричного транспорту в Україні здійснюється у відповідності до Закону України «Про міський електричний транспорт», Правил надання населенню послуг 3 перевезень міським електротранспортом, Постанови Кабінету Міністрів України «Про затвердження критеріїв, за якими оцінюється ступінь ризику від провадження господарської діяльності у сфері міського електричного транспорту (трамвай, тролейбус) та визначається періодичність проведення планових заходів державного нагляду (контролю) Державною службою 3 безпеки на транспорті», Порядку формування тарифів на послуги міського електричного транспорту (трамвай, тролейбус), Порядку формування тарифів на послуги міського електричного транспорту (метрополітену), Правил охорони праці на міському електричному транспорті, Положення про порядок службового розслідування дорожньо-транспортних пригод на міському електротранспорті [8]. Трубопровідний транспорт. Функціонування 
трубопровідного транспорту в Україні головним чином регламентується: Законом України «Про трубопровідний транспорт»; Постановою Кабінету Міністрів України «Про плату за транзит нафти, газу та аміаку трубопровідним транспортом через територію України»; Наказом Міністерства фінансів України «Про митні формальності на трубопровідному транспорті та лініях електропередачі»; Інструкцією про порядок взаємодії посадових осіб митних органів і відповідальних осіб структурних підрозділів газотранспортної системи при здійсненні митного контролю природного газу, переміщуваного через митний кордон України трубопровідним транспортом [8].

Висновки 3 проведеного дослідження. Виявлена із застосуванням пошукової системи «Законодавство України» численність і типовість нормативно-правових актів, що регламентують розвиток суб'єктів автомобільного транспорту, дорожнього господарства, залізничного транспорту, повітряного транспорту, морського та річкового транспорту, міського електричного транспорту та трубопровідного транспорту актуалізують необхідність їх уніфікації, консолідації та кодифікації у вигляді Транспортного кодексу України як основи законодавчого забезпечення розвитку транспортної інфраструктури України. Транспортний кодекс України має стати стійким нормативним підгрунтям для забезпечення стратегічного розвитку транспортної інфраструктури країни. Також передбачається тактична інтенсифікація розвитку транспортної інфраструктури України через періодичне прийняття строкових програмних документів на кшталт наразі чинної Національної транспортної стратегії України на період до 2030 року, аналіз структури та змісту якої складає перспективи подальших досліджень.

\section{Перелік посилань}

1. Україна посідає 87-е місце у світі за рівнем розвитку транспортної інфраструктури - Global Competitiveness Index. URL: https://gordonua.com/ukr/ news/money/ukrajina-zajmaje-87-e-mistse-v-sviti-za-rivnem-rozvitku-transportnojiinfrastrukturi-global-competitiveness-index-249272.html (дата звернення : 15.09.2019).

2. Транспортна інфраструктура: світло у кінці тунелю. URL: https://forumkyiv.org/uk/analytics/transportna-infrastruktura:-svitlo-u-kinci-tunelyu (дата звернення : 15.09.2019).

3. Ляшенко О. Нормативно-правове регулювання в механізмі державного управління транспортної інфраструктури. Теоретичні та прикладні питання державотворення. 2013. Вип. 12. URL: http://nbuv.gov.ua/UJRN/tppd_2013_12_9 (дата звернення : 17.09.2019).

4. Дульфан С.Б. Нормативно-правове забезпечення розвитку транспортної інфраструктури міст. Держава та регіони. Серія: Державне управління. 2014. № 3. С. 79-85.

5. Про затвердження Авіаційних правил України, Частина 47 «Правила реєстрації цивільних повітряних суден в Україні»: Наказ Державної авіаційної служби України від 5 лютого 2019 року № 153. URL: https://zakon.rada.gov.ua/ laws/show/z0240-19 (дата звернення : 18.09.2019). 
6. Про визнання такими, що втратили чинність, деяких наказів Міністерства транспорту та зв'язку України та Міністерства інфраструктури України: Наказ Міністерства інфраструктури України від 13 серпня 2015 року № 310. URL: https://zakon.rada.gov.ua/laws/show/z1039-15 (дата звернення : 18.09.2019).

7. Про схвалення Національної транспортної стратегії України на період до 2030 року: Розпорядження Кабінету Міністрів України від 30 травня 2018 року № 430-p. URL: https://zakon.rada.gov.ua/laws/show/430-2018-p (дата звернення : 18.09.2019).

8. Законодавство України: пошукова система. URL: https://zakon.rada. gov.ua/laws (дата звернення : 19.09.2019).

\section{References}

1. Ukraine ranks 87th place in the world in terms of the transport infrastructure development - Global Competitiveness Index [Ukraina posidaie 87-e mistse u sviti za rivnem rozvytku transportnoi infrastruktury - Global Competitiveness Index], available at: https://gordonua.com/ukr/ news/money/ukrajina-zajmaje-87-e-mistse-vsviti-za-rivnem-rozvitku-transportnoji-infrastrukturi-global-competitiveness-index249272.html (last accessed 15.09.2019).

2. Transport infrastructure: light at the end of tunnel [Transportna infrastruktura: svitlo u kintsi tuneliu], available at: https://forumkyiv.org/ uk/analytics/transportna-infrastruktura:-svitlo-u-kinci-tunelyu (last accessed 15.09.2019).

3. Liashenko, O. (2013), Legal regulation in the mechanism of the state management of transport infrastructure [Normatyvno-pravove rehuliuvannia $\mathrm{v}$ mekhanizmi derzhavnoho upravlinnia transportnoi infrastruktury]. Theoretical and applied issues of the state formation, Issue 12, available at: http://nbuv.gov.ua/UJRN/tppd_2013_12_9 (last accessed 17.09.2019).

4. Dulfan, S.B. (2014), Legal support for the development of the urban transport infrastructure [Normatyvno-pravove zabezpechennia rozvytku transportnoi infrastruktury mist]. State and regions. Series: Public administration, No 3. P. 79-85.

5. On approval of the Aviation Rules of Ukraine, Part 47 «Rules of registration of the civil aircraft in Ukraine»: Order of the State aviation service of Ukraine of February 5, 2019 No 153 [Pro zatverdzhennia Aviatsiinykh pravyl Ukrainy, Chastyna 47 «Pravyla reiestratsii tsyvilnykh povitrianykh suden v Ukraini»: Nakaz Derzhavnoi aviatsiinoi sluzhby Ukrainy vid 5 liutoho 2019 roku No 153], available at: https://zakon.rada.gov.ua/ laws/show/z0240-19 (last accessed 18.09.2019).

6 . On the declaration of expiration of certain orders of the Ministry of transport and communications of Ukraine and the Ministry of infrastructure of Ukraine: Order of the Ministry of infrastructure of Ukraine of August 13, 2015 No 310 [Pro vyznannia takymy, shcho vtratyly chynnist, deiakykh nakaziv Ministerstva transportu ta zviazku Ukrainy ta Ministerstva infrastruktury Ukrainy: Nakaz Ministerstva infrastruktury Ukrainy vid 13 serpnia 2015 roku No 310], available at: https://zakon.rada.gov.ua/laws/show/z1039-15 (last accessed 18.09.2019). 
7. On approval of the National transport strategy of Ukraine until 2030: Ordinance of the Cabinet of Ministers of Ukraine of May 30, 2018 No 430-r [Pro skhvalennia Natsionalnoi transportnoi stratehii Ukrainy na period do 2030 roku: Rozporiadzhennia Kabinetu Ministriv Ukrainy vid 30 travnia 2018 roku No 430-r], available at: https://zakon.rada.gov.ua/laws/show/430-2018-p (last accessed 18.09.2019).

8. The legislation of Ukraine: search system [Zakonodavstvo Ukrainy: poshukova systema], available at: https://zakon.rada.gov.ua/laws (last accessed 19.09.2019).

\section{РЕФЕРАТИ РЕФЕРАТЫ ABSTRACTS}

УДК 346.7:656; JEL Classification: L 98

ДМИтрісва О.І. ЗАКОНОДАВЧЕ ЗАБЕЗПЕЧЕННЯ РОЗВИТКУ ТРАНСПОРТНОЇ ІНФРАСТРУКТУРИ УКРАЇНИ

Мета: ідентифікація чинного законодавчого підгрунтя розвитку транспортної інфраструктури України. Методика дослідження: метод аналізу та синтезу, системний підхід, порівняльний аналіз. Результати: iз застосуванням пошукової системи «Законодавство України» виявлено чинні акти органів законодавчої та виконавчої влади, нормами яких наразі регламентується розвиток транспортної інфраструктури України як в цілому, так і за такими іiі елементами як «автомобільний транспорт», «дорожне господарство», «залізничний транспорт», «повітряний транспорт», «морський i річковий транспорт», «міський електричний транспорт» i «трубопровідний транспорт». Наукова новизна: численність і типовість нормативно-правових актів, що регламентують розвиток елементів транспортної інфраструктури України, актуалізують необхідність їх уніфікації, консолідації та кодифікації у вигляді Транспортного кодексу України як стійкого законодавчого підгрунтя для забезпечення стратегічного розвитку транспортної інфраструктури країни. Забезпечення тактичної інтенсифікації розвитку транспортної інфраструктури України передбачається через періодичне прийняття строкових програмних документів на кшталт наразі чинної Національної транспортної стратегії України на період до 2030 року, аналіз структури та змісту якої складає перспективи подальших досліджень. Практична значущість: надані рекомендації 3 удосконалення законодавчого забезпечення розвитку транспортної інфраструктури України складають інтерес для органів державної влади, до відання яких належить регулювання розвитку автомобільного транспорту, дорожнього господарства, залізничного транспорту, повітряного транспорту, морського та річкового транспорту, міського електричного транспорту та трубопровідного транспорту.

Ключові слова: транспортна інфраструктура; законодавча база; автомобільний транспорт; дорожнє господарство; залізничний транспорт; повітряний транспорт; морський і річковий транспорт; міський електричний транспорт; трубопровідний транспорт. 


\section{УДК 346.7:656; JEL Classification: L 98}

\section{ДМИтрИева О.И. ЗАКОНОДАТЕЛЬНОЕ ОБЕСПЕЧЕНИЕ}

\section{РАЗВИТИЯ ТРАНСПОРТНОЙ ИНФРАСТРУКТУРЫ УКРАИНЫ}

Цель: идентификация действующей законодательной базы развития транспортной инфраструктуры Украины. Методика исследования: метод анализа и синтеза, системный подход, сравнительный анализ. Результаты: с применением поисковой системы «Законодательство Украины» выявлено действующие акты органов законодательной и исполнительной власти, нормами которых сейчас регламентируется развитие транспортной инфраструктуры Украины как в целом, так и по таким ее элементами как «автомобильный транспорт», «дорожное хозяйство», «железнодорожный транспорт», «воздушный транспорт», «морской и речной транспорт», «городской электрический транспорт» и «трубопроводный транспорт». Научная новизна: многочисленность и типичность нормативно-правовых актов, регламентирующих развитие элементов транспортной инфраструктуры Украины, актуализируют необходимость их унификации, консолидации и кодификации в виде Транспортного кодекса Украины как устойчивой законодательной основы для обеспечения стратегического развития транспортной инфраструктуры страны. Обеспечение тактической интенсификации развития транспортной инфраструктуры Украины предусматривается через периодическое принятие срочных программных документов по примеру действующей Национальной транспортной стратегии Украины на период до 2030 года, анализ структуры и содержания которой составляет перспективы дальнейших исследований. Практическая значимость: разработанные рекомендации по совершенствованию законодательного обеспечения развития транспортной инфраструктуры Украины составляют интерес для органов государственной власти, к ведению которых относится регулирование развития автомобильного транспорта, дорожного хозяйства, железнодорожного транспорта, воздушного транспорта, морского и речного транспорта, городского электрического транспорта и трубопроводного транспорта.

Ключевые слова: транспортная инфраструктура; законодательная база; автомобильный транспорт; дорожное хозяйство; железнодорожный транспорт; воздушный транспорт; морской и речной транспорт; городской электрический транспорт; трубопроводный транспорт.

\section{UDC 346.7:656; JEL Classification: L 98}

Dmytriieva O. LEGISLATIVE SUPPORT OF THE TRANSPORT INFRASTRUCTURE DEVELOPMENT OF UKRAINE

Purpose: identification of the current legislative support of the transport infrastructure development of Ukraine. Methodology of research: method of analysis and synthesis, systematic approach, comparative analysis. Findings: the use of search system "The legislation of Ukraine" revealed the valid acts of the legislative and executive bodies, which is currently regulating the transport infrastructure development of Ukraine as a whole, as well as in such elements as "road transport", 
"highways", "railways", "air transport", "sea and river transport", "urban electric transport", "pipeline transport". Originality: the multiplicity and typicality of the legal acts regulating the development of the elements of the transport infrastructure of Ukraine actualize the need for their unification, consolidation and codification in the form of the Transport code of Ukraine as a stable legislative basis for ensuring the strategic development of the transport infrastructure of the country. Support of the tactical intensification of the development of the transport infrastructure of Ukraine is envisaged through the periodic adoption of the urgent programmatic documents such as the current National transport strategy of Ukraine for the period until 2030, the analysis of the structure and content of which provides the prospects for the further researches. Practical value: recommendations given to improve the legislative support for the development of the transport infrastructure of Ukraine are of interest to the public authorities, which are responsible for regulating the development of road transport, highways, railways, air transport, sea and river transport, urban electric transport and pipeline transport.

Key words: transport infrastructure; legislative framework; road transport; highways; railways; air transport; sea and river transport; urban electric transport; pipeline transport.

\section{Відомості про авторів / Сведения об авторах / About the Authors}

Дмитрієва Оксана Іллівна - кандидат економічних наук, доцент, Харківський національний автомобільно-дорожній університет, доцент кафедри управління та адміністрування, м. Харків, Україна; е-mail: oksanahnadu@gmail.com; ORCID ID: 0000-0001-9314-350X. Моб. (063) 353-7998 .

Дмитриева Оксана Ильинична - кандидат экономических наук, доцент, Харьковский национальный автомобильно-дорожный университет, доцент кафедры управления и администрирования, г. Харьков, Украина.

Dmytriieva Oksana - PhD (Economics), Associate Professor, Kharkiv National Automobile and Highway University, Associate Professor of the Department of Management and Administration, Kharkiv, Ukraine. 